\title{
Management of Primary Mediastinal Yolk Sac Tumors: A Single Institution Experience with 10 Patients
}

\section{Yang Yu}

Sichuan University West China Hospital

Yong Jiang

Sichuan University West China Hospital

Xuanwei Zhang

Sichuan University West China Hospital

\section{Feifei $\mathrm{Na}$}

Sichuan University West China Hospital

\section{Weigang Xiu}

Sichuan University West China Medical Center

\section{Yanying Li}

Sichuan University West China Hospital

\section{Meijuan Huang}

Sichuan University West China Hospital

You Lu

Sichuan University West China Hospital

Youling Gong ( $\nabla$ gongyouling@hotmail.com )

Department of Thoracic Oncology and State Key Laboratory of Biotherapy,Cancer Center,West China Hospital,Sichuan University,Chengdu,China https://orcid.org/0000-0001-8230-5892

\section{Research Article}

Keywords: Primary mediastinal yolk sac tumors, chemotherapy, surgery

Posted Date: March 9th, 2021

DOI: https://doi.org/10.21203/rs.3.rs-279668/v1

License: @ (i) This work is licensed under a Creative Commons Attribution 4.0 International License. Read Full License 


\section{Abstract}

Background: Primary mediastinal yolk sac tumors is a kind of primary mediastinal non-seminomatous germ cell tumor. The current treatment strategies in primary mediastinal non-seminomatous germ cell tumor is neoadjuvant chemotherapy followed by residual mass surgical resection . We reviewed our institutional 5 years' experience with Primary mediastinal yolk sac tumors who treated with platinum-based neoadjuvant chemotherapy and extended resection.

Methods $₫$ We experienced 10 cases of Primary mediastinal yolk sac tumors from October of 2014 to October of 2019.7 patients received preoperative platinum-based chemotherapy followed by surgical resection of residual mediastinal mass. The other 3 patients were received initial surgical resection without preoperative chemotherapy.

Results囚R0 resection was achieved in 8 patients (80\%), and R2 resection

was in the other 2 patients (20\%). All the 7 patients with neoadjuvant chemotherapy were R0 resections, however all of them had viable tumor in their surgical specimen. Morbidities after surgery occurred in 2 patients, including 2 pneumonias , 1 type I respiratory failure and 1 acute left heart failure, and They were died within 2 months after surgery. At the time of writing , 3 patients are alive without evidence of disease,7 patients died, of which 5 patients have died of tumor-related causes and 2 died of postoperative complications. 8 patients were included in the follow-up. Among them 7 patients experienced progressed within one year. 8 patients were included in the follow-up,mPFS and mOS in 8 patients were 3.7 months (2.6-41.3m) and 23.15 months (8.6-41.3m) , respectively. The 7 patients with neoadjuvant chemotherapy followed by surgical resection of residual diseases, 2-year survival rate was $57.1 \%$,The 3 -year survival rate was $28.6 \%$

Conclusion: An aggressive, multidisciplinary treatment including neoadjuvant chemotherapy followed by residual mass surgical resection is the optimal treatment and can be associated with prolonged survival.

\section{Introduction}

Primary mediastinal yolk sac tumors (PMYST) is a kind of primary mediastinal non-seminomatous germ cell tumors (PMNSGCT) . It is rare. Germ cell tumors (GCTs) usually arising in the gonads, and extragonadal origin accounts for only $1 \%$ to $5 \%$ of GCTs (1), nevertheless PMYSTs only account for $15 \%$ of all mediastinum GCTs(2).

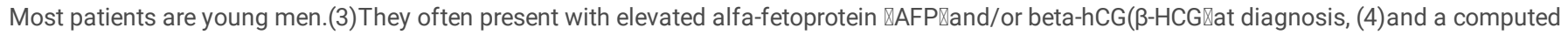
tomographic scan of the chest aways revealed a giant mediastinal mass.

PMYST carries a very poor prognosis. The optimal treatment for PMNSGCT is chemotherapy followed by radical resection for residual mass. (5,6)At some centers, surgery is considered even in cases of the first-line chemotherapy with non-responders, because of dismal results with second-line chemotherapy. $(7,8)$ Despite aggressive treatment, the prognosis of these patients is still poor.(9)

Literatures on PMYST are rare. Here is a review of our single-center experience.

\section{Material And Methods}

A retrospective study of 10 patients with PMYST who underwent extended resection referred to the West China hospital,Sichuan University , from October of 2014 to October of 2019, were performed. Tumor response was assessed with the use of RECIST, version 1.1. The pathological diagnosis in the surgical specimen were registered by pathologist (Figure 1 and Figure 2 ).

\section{Statistics}

Survival data was calculated from the date of diagnosis, until their last known follow-up day, or date of death. Actuarial survival curves were calculated according to the Kaplan-Meier method.

\section{Result}

\section{Patient and Tumor Characteristics}

A retrospective study of 10 patients with PMYST who underwent extended resection referred to the West China hospital,Sichuan University , from October of 2014 to October of 2019, were performed.Patients' characteristics are summarized in Table 1.

\section{Radiographic and Pathologic Response to Preoperative Chemotherapy}

7 patients experienced some degree of radiographic tumor shrinkage from the preoperative chemotherapy. 6 patients met the criterion for PR(Figure 3)and 1 patients had SD. 8 of the 10 patients (80\%) underwent an R0 resection and 2 (20\%) an R2 resection. All the 7 patients with neoadjuvant chemotherapy were R0 resections, however All patients had viable tumor cells in their surgical specimen.

Operation and Surgical Complications 
Details of surgery and complications are outlined in Table 2. Morbidities after surgery occurred in 2 patients, including a postoperative pneumonia and type I respiratory failure in 1 patient, and pneumonia,a persistent sinus tachycardia and acute left heart failure in the other one. They were died within 2 months after surgery.

\section{Recurrence and Survival}

At the time of writing, 3 patients are alive without evidence of disease,7 patients died, Of which 5 patients have died of tumor-related causes and 2 died of postoperative complications.

8 patients were included in the follow-up, among them 7patients experienced progressed. 6 patients progressed mainly in the form of metastasis, such as lung, brain, liver, bone, 1 had experienced anterior mediastinum recurrence which was due to R2 excision. mPFS and mOS in 8 patients were 3.7 months (2.6$8.6 \mathrm{~m})$ and 23.15 months $(8.6-41.3 \mathrm{~m})$, respectively . The 7 patients with neoadjuvant chemotherapy followed by surgical resection of residual diseases, 2 -year survival rate was $57.1 \%$,the 3 -year survival rate was $28.6 \%$.

\section{Discussion}

The majority of Germ cell tumors (GCT) originates from gonad, whereas only $1 \%$ to $5 \%$ of all GCT may occur in the extragonadal places.(10)Extragonadal germ cell tumors can occur in the mid-line of the body from the retroperitoneum, anterior mediastinum and in other areas such as the pineal gland or the coccyx .(11)The mediastinum represents the most common site of extragonadal primaries (50\% to $70 \%)$. (3)Primary malignant mediastinal germ cell tumors(PMMGCT) are divided into two broad groups, primary mediastinal seminomatous germ cell tumors (PMSGCT)and primary mediastinal nonseminomatous germ cell tumors (PMNSGCT). (12) PMNSGCT includes choriocarcinoma, teratoma,embryonic carcinoma, and yolk sac tumor(13). Primary mediastinal yolk sac tumors(PMYST) of the mediastinum is rather rare.

PMYST carries a very poor prognosis.Prognostic data of patients with neoadjuvant followed by radical resection for residual mass are more reported for PMNSGCT. Walsh et al.(5) reported 20 cases of PMNSGCT囚from 1993 to 1998, 9 of them were PMYST, and the overall survival at 2 years was $58 \%$. Kesler et al. (6)Reported 158 cases of PMNSGCT, from 1981 to 1998, 76 cases of PMYST with 2-year overall survival of 56\% .Sarkaria et al. (8)Reported from 1980 to 2008. 57 cases of PMNSGCT, 16 of them were PMYST. The median OS from time of chemotherapy were 31.5 months. OS at 2 years were $56 \%$. In our series, the 2-year OS of PMYST was $57.1 \%$, the 3 -year survival rate was $28.6 \%$ which was very similar to prognosis of PMNSGCT reported previously. The median overall survival was 25.5 months.

Elevated AFP and $\beta-\mathrm{HCG}$ at diagnosis is seen in $90 \%$ of nonseminomatous germ cell tumor patients. (11) Serum AFP levels are useful for the diagnosis and may guide treatment. In our report, AFP information was available for 6 patients receiving neoadjuvant chemotherapy, which decreased after chemotherapy and elevated when the tumor recurred, but no one was approaching normal levels. All the 7 patients receiving neoadjuvant chemotherapy were R0 resection, however, the surgical specimen of these patients exhibited viable tumors.

Due to the rarity of PMYST, oncologists recommend treating this disease like testes NSGCT. Multiple clinical studies have proved that cisplatin based chemotherapy combined with surgical resection of residual diseases is one of the most successful modes of multidisciplinary therapy(3,6,8). Firstly, PMNSGCT always located in the anterior mediastinum close to important mediastinal anatomical structures such as the great vessels, the lung and the heart and so on . It is often impossible to achieve complete excision by initial surgery. Moreover, PMNSGCT are sensitive to first-line chemotherapy, however, secondline salvage chemotherapy are ineffective, with only approximately $5 \%-10 \%$ of patients. $(4,14)$. We recommend treat in a more aggressive way. Surgical resection was encouraged if resection was feasible after first-line chemotherapy, even if Tumor regression did not achieve partial response. Finally, After cisplatin-based chemotherapy for PMNSGCT, viable tumor cells were still found in their surgical specimen (6). In our study, 7 patients underwent surgical resection after preoperative chemotherapy, of which 6 patients reached partial response and one with stable disease. However active tumor cells was still detected in all postoperative pathological specimens. Therefore, our data also support the view of surgical resection of residual tumor mass after chemotherapy.

In conclusion, PMYST is rare, and the prognosis is poor. A multidisciplinary aggressive approach including neo-adjuvant chemotherapy followed by surgical resection is the optimal treatment, but overall survival is still not satisfactory. We need to accumulate more experience and explore new treatments for this rare malignancy.

\section{Declarations}

Ethics approval and consent to participate】the Biomedical Ethics Committee of West China Hospital of Sichuan University approved the study.

Consent for publication $\square$ Not applicable.

Availability of data and materialsロAll data generated or analysed during this study are included in this published article.

Competing interests[The authors declare that they have no competing interests

Funding $[$ Not applicable

Authors' contributions $\square$ 


\begin{tabular}{|ll|}
\hline Yang Yu & Mading contributions to the conception ,design of the work,interpretation of data,drafted the work \\
\hline Yong Jiang & Mading contributions to interpretation of data \\
\hline Xuanwei Zhang & Mading contributions to drafted the work \\
\hline Feifei Na & Mading contributions to Analysis of data \\
\hline Weigang Xiu & Mading contributions to interpretation of data \\
\hline Meijuan Huang & Mading contributions to substantively revised it \\
\hline You Lu & Mading contributions to substantively revised it \\
\hline Youling Gong & Mading contributions to the conception,design of the work and substantively revised it \\
\hline
\end{tabular}

\section{Acknowledgement}

We would like to thank TopEdit (www.topeditsci.com) for English language editing of this manuscript.

\section{References}

1. McKenney JK, Heerema-McKenney A, Rouse RV: Extragonadal germ cell tumors: a review with emphasis on pathologic features, clinical prognostic variables, and differential diagnostic considerations. Adv Anat Pathol 2007, 14:69-

2. Liu B, Lin G, Liu J, Liu H, Shang X, Li J. Primary mediastinal yolk sac tumor treated with platinum-based chemotherapy and extended resection: Report of seven cases. Thorac Cancer. 2018;9(4):491-494.

3. Rodney AJ, Tannir NM, Siefker-Radtke AO et al. Survival outcomes for men with mediastinal germ-cell tumors: The University of Texas M. D. Anderson Cancer Center experience. Urol Oncol 2012; 30 (6): 879-

4. Rosti G, Secondino S, Necchi A, Fornarini G, Pedrazzoli P. Primary mediastinal germ cell tumors. Semin Oncol. 2019 Apr;46(2):107-111.

5. Walsh GL, Taylor GD, Nesbitt JC, Amato RJ. Intensive chemotherapy and radical resections for primary nonseminomatous mediastinal germ cell tumors. Ann Thorac Surg 2000; 69 (2): 337- 343-344.

6. Kesler KA, Rieger KM, Ganjoo KN et al. Primary mediastinal nonseminomatous germ cell tumors: The inflfluence of postchemotherapy pathology on longterm survival after surgery. J Thorac Cardiovasc Surg 1999;

7. Schneider BP, Kesler KA, Brooks JA, et al. Outcome of patients with residual germ cell or non-germ cell malignancy after resection of primary mediastinal nonseminomatous germ cell cancer. J Clin Oncol 2004;22:1195-1200.

8. Vuky J, Bains M, Bacik J, et al. Role of postchemotherapy adjunctive surgery in the management of patients with nonseminoma arising from the mediastinum. J Clin Oncol 2001;19:682-688.

9. Sarkaria IS, Bains MS, Soos S, et al. Resection of primary mediastinal non-seminomatous germ cell tumors. A 28-year experience at Memorial SloanKettering Cancer Center. J Thorac Oncol 2011;6:1236-41.

10. McKenney JK, Heerema-McKenney A, Rouse RV: Extragonadal germ cell tumors: a review with emphasis on pathologic features, clinical prognostic variables, and differential diagnostic considerations. Adv Anat Pathol 2007, 14:69-

11. Scholz M, Zehender M, Thalmann GN. Etragonadal retroperitoneal germ cell tumor: evidence of origin in the tetis. Ann Oncol 2002;13:121-4

12. Kesler KA, Stram AR, Timsina LR, Turrentine MW, Brown JW, Einhorn LH. Outcomes following surgery for primary mediastinal nonseminomatous germ cell tumors in the cisplatin era. J Thorac Cardiovasc Surg. 2020 Apr 22:S0022-5223(20)30995-8.

13. Bremmer F, Strobel P. Mediastinal germ cell tumors. Pathologe 2016; 37 (5): $441-$

14. Hartmann J, Einhorn L, Nichols C, et al. Second-line chemotherapy in patients with relapsed extragonadal non seminomatous germ cell tumors: Results of an international multicenter analysis. J Clin Oncol 2001;19:1641- 8.

\section{Tables}

Table 1. Clinical characteristics of ten patients 


\begin{tabular}{|c|c|c|c|c|c|c|c|c|c|c|}
\hline $\begin{array}{l}\text { Case } \\
\text { no. }\end{array}$ & Age & Symptom & $\begin{array}{l}\text { AFP before } \\
\text { Chemotherapy } \\
\text { Dug/L口 }\end{array}$ & $\begin{array}{l}\text { Preoperative } \\
\text { Chemotherapy』cycle/drug }\end{array}$ & Course & $\begin{array}{l}\text { Surgical } \\
\text { (approach) }\end{array}$ & Resection & $\begin{array}{l}\text { Major } \\
\text { postoperative } \\
\text { complications }\end{array}$ & $\begin{array}{l}\text { Postoperative } \\
\text { chemotherapy } \\
\text { (cycle, drug) }\end{array}$ & RT \\
\hline 1 & 23 & $\begin{array}{l}\text { Cough } \\
\text { Chest pain } \\
\text { svcs }\end{array}$ & ID & 6,BEP & PR & $\begin{array}{l}\text { Yes } \\
\text { (MS囚 }\end{array}$ & Ro & None & ND & ND \\
\hline 2 & 25 & $\begin{array}{l}\text { Cough } \\
\text { Dyspnea } \\
\text { Fever }\end{array}$ & 2114 & 3,BEP & $\mathrm{PR}$ & $\begin{array}{l}\text { Yes } \\
\text { (MS } \square\end{array}$ & Ro & None & 3,EP & $\begin{array}{l}\text { Yes } \\
(50 .\end{array}$ \\
\hline 3 & 44 & $\begin{array}{l}\text { Cough } \\
\text { SVCS } \\
\text { hemoptysis }\end{array}$ & $\$ 1210$ & $\begin{array}{l}\text { 1,EP } \\
4, \mathrm{BEP}\end{array}$ & $\mathrm{PR}$ & $\begin{array}{l}\text { Yes } \\
\text { (MS囚 }\end{array}$ & Ro & None & ND & $\begin{array}{l}\text { Yes } \\
(501\end{array}$ \\
\hline 4 & 17 & $\begin{array}{l}\text { Chest pain } \\
\text { Fever }\end{array}$ & 650 & 4,BEP & PR & $\begin{array}{l}\text { Yes } \\
\text { (RMSAT区 }\end{array}$ & Ro & None & 2,BEP & ND \\
\hline 5 & 32 & $\begin{array}{l}\text { Dyspnea } \\
\text { Fever } \\
\text { SVCS }\end{array}$ & $\$ 1210$ & 4,BEP & $\mathrm{PR}$ & $\begin{array}{l}\text { Yes } \\
\text { (MS }\end{array}$ & Ro & None & ND & ND \\
\hline 6 & 20 & $\begin{array}{l}\text { Fever } \\
\text { Chest pain }\end{array}$ & $\$ 1210$ & $\begin{array}{l}2, \mathrm{EP} \\
1, \mathrm{BEP}\end{array}$ & SD & $\begin{array}{l}\text { Yes } \\
\text { (MS』 }\end{array}$ & Ro & None & 4,EP & $\begin{array}{l}\text { Yes } \\
(501\end{array}$ \\
\hline 7 & 23 & $\begin{array}{l}\text { Dyspnea } \\
\text { Chest pain } \\
\text { svcs }\end{array}$ & $₫ 1210$ & $\begin{array}{l}3, \mathrm{EP} \\
2, \mathrm{BEP}\end{array}$ & PR & $\begin{array}{l}\text { Yes } \\
\text { (MS区 }\end{array}$ & Ro & None & 4,EP & ND \\
\hline 8 & 33 & Dyspnea & ND & ND & None & $\begin{array}{l}\text { Yes } \\
\text { (MS囚 }\end{array}$ & R2 & $\begin{array}{l}\text { Pneumonia, } \\
\text { Heart failure }\end{array}$ & ND & ND \\
\hline 9 & 22 & $\begin{array}{l}\text { Dyspnea } \\
\text { Chest pain }\end{array}$ & ND & ND & None & $\begin{array}{l}\text { Yes } \\
\text { (MS囚 }\end{array}$ & Ro & $\begin{array}{l}\text { Pneumonia, } \\
\text { Respiratory } \\
\text { failure }\end{array}$ & ND & ND \\
\hline 10 & 23 & $\begin{array}{l}\text { Chest pain } \\
\text { Night } \\
\text { sweats }\end{array}$ & $\$ 1210$ & ND & None & $\begin{array}{l}\text { Yes } \\
\text { (LMSAT区 }\end{array}$ & R2 & None & 6,BEP & $\begin{array}{l}\text { Yes } \\
(61 .\end{array}$ \\
\hline
\end{tabular}

Table 2. Operation-related factors 


\begin{tabular}{|c|c|}
\hline & $N=10$ \\
\hline \multicolumn{2}{|l|}{ Surgical approach } \\
\hline Median sternotomy & 8 \\
\hline Muscle-sparing axillary thoracotomy & 2 \\
\hline \multicolumn{2}{|l|}{ Site of combined resection } \\
\hline Vascular prosthetic replacement & 2 \\
\hline Venous sheath resection & 5 \\
\hline Arterial sheath excision & 3 \\
\hline \multicolumn{2}{|l|}{ Lung (type of resection) } \\
\hline left total pneumonectomy & 1 \\
\hline Partial resection & 7 \\
\hline Right atrial appendage & 1 \\
\hline Phrenic nerve & 1 \\
\hline Lymph node dissection & 3 \\
\hline Blood loss (ml) & 733(100-2500ML) \\
\hline Patients who received blood transfusion & 4 \\
\hline \multicolumn{2}{|l|}{ Resection } \\
\hline Ro & 8 \\
\hline $\mathrm{R} 2$ & 2 \\
\hline \multicolumn{2}{|l|}{ Postoperative complications } \\
\hline pneumonia & 2\case 8 and $9 \bigotimes$ \\
\hline Respiratory failure & 1】case 9囚 \\
\hline heart failure & 1囚case 8\ \\
\hline R0 :no residual tumor;R2: macroscopic res & dual tumor. \\
\hline
\end{tabular}

\section{Figures}
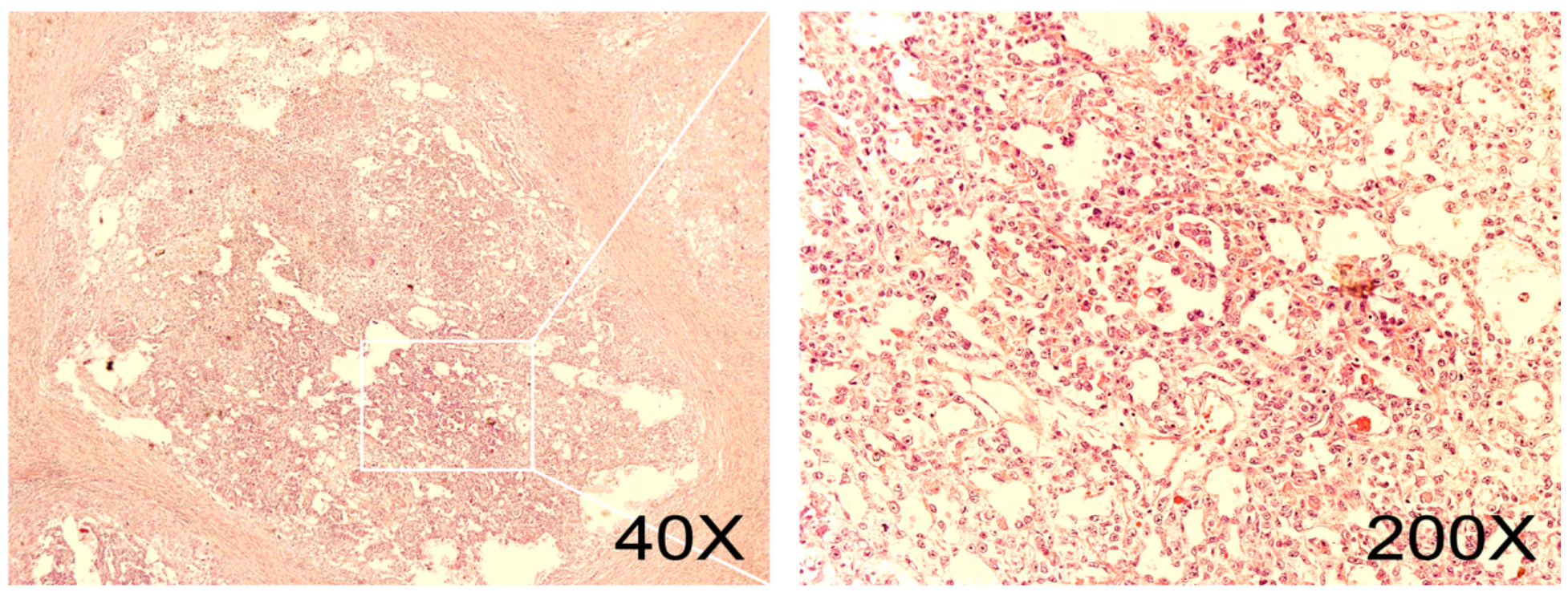

\section{Figure 1}

Histologic patterns of mediastinal yolk sac tumors (YST). 

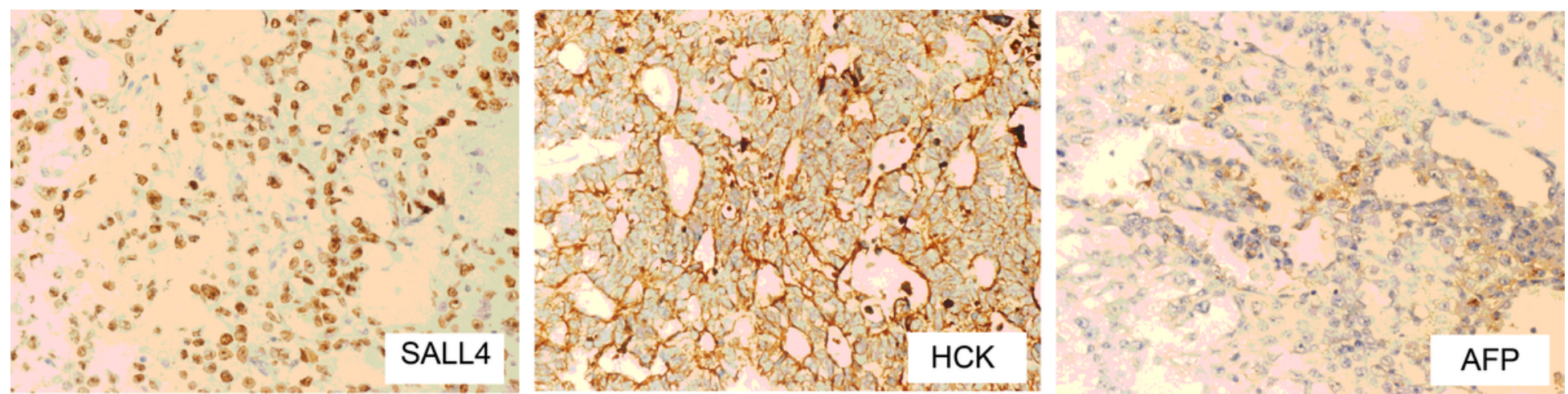

Figure 2

Characteristic staining pattern of mediastinal yolk sac tumors (YST). SALL4(+). HCK(+). AFP(+).
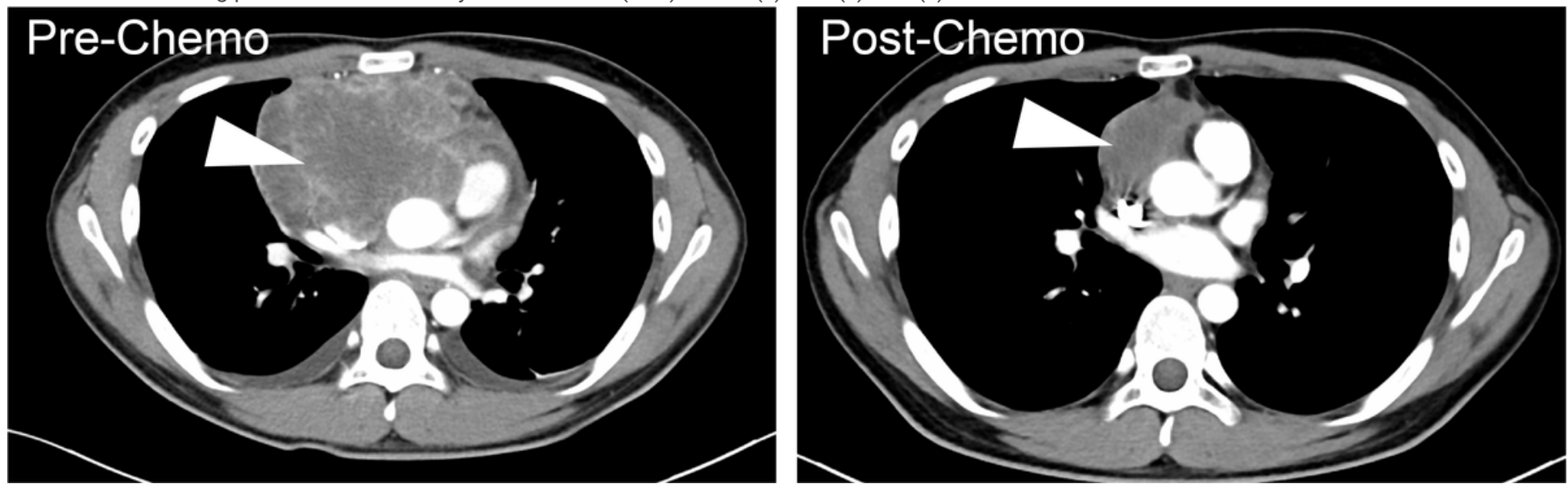

Figure 3

Contrast-enhanced computed tomography (CT) of case 2. CT scan of the chest before preoperative chemotherapy and CT scan of the chest after 3cycles preoperative chemotherapy. 